\title{
The Prisoner as Testimonialista: A Book Review of Bobby V. Villagracia's Selda Dos (Manila City Jail)
}

Noel Christian A. Moratilla

Two years ago, the National Bilibid Prison, also known as the National Penitentiary or Bilibid, was thrust into the national limelight for the wrong reasons. I refer in particular to issues concerning the alleged manufacture of illegal drugs within its walls that subjected the institution to intense public scrutiny and contributed to the further polarization of an already embattled country. Invoking their principle of conducting investigations "in aid of legislation," the two chambers of Congress even called for separate, widely telecast hearings to supposedly ferret out the "truths" regarding drug trade in prison, such as its connection to certain government officials and the extent to which it has contributed to the country's drug menace. But as expected, the issue was muddled by partisan interests, with politicians and their minions spewing vitriol in public and bandying accusations of political persecution, grandstanding, and opportunism. Like other national issues, the so-called Bilibid drug trade revealed fissures within the ruling class via the fractured discourse of traditional politicians.

That the country's prison system is fraught with anomalies (e.g., padrino system, prostitution, possession of firearms and ammunition, the manufacture and peddling of illegal substances) had constituted public knowledge even before the imbroglio broke out, thanks to depictions of prison life in popular culture, as well as the stories coming from former convicts themselves. True-to-life films such as Baby Ama and Death Row, and more recently, the teleserye Ang Probinsiyano, the television remake 
of a Fernando Poe, Jr. classic, have shown, in ostensibly exaggerated or melodramatic fashion, the despair and brutality of life in detention. The penal system seems to constitute a painful travesty of justice itself, with prison officials and privileged inmates exercising undue influence. An institution that is supposed to punish or rehabilitate (depending on how one would like to view it) transgressors of the law has served as a laboratory for cruelty and power play. To compound it all, convicts are stigmatized and discriminated against for the rest of their lives. Once released, former prisoners do not completely enjoy their newfound freedom. They inevitably become objects of fear, suspicion and/or derision, perpetually anathematized and unable to be reintegrated into mainstream society. Eking out a difficult existence on the fringe of society and neglected or avoided even by their own families, ex-convicts realize that, in many respects, life behind bars is better than life after prison. As O'Brien (2001) observed, "The status of ex-offender is only one part of the person's identity, yet it can become the most prominent defining characteristic for representing self. With the label comes the baggage of distrust and lack of credibility that may foster an attitude of hopelessness" (p. 28).

Selda Dos (Manila City Jail), published by the University of the Philippines Press in 2016, is about life in detention. The book is no work of fiction: it is the first-person account of the author, Bobby Villagracia, about his almost three-month imprisonment at the Manila City Jail after being accused of malversation of public funds while serving as a minor government official in his native Camarines Norte-a charge that he repeatedly denies in the book. (The charge involved just around 30 thousand pesos, a measly amount compared to the millions of pesos that some politicians allegedly steal from government coffers.) Villagracia narrates his experiences as a city jail detainee and muses on how it affected his life. A significant part of the book relates the author's psychological and physical struggles, including harassment and intimidation in the hands of toughies, gang leaders, and even prison officers, confirming the all-too-familiar dour representations of prison life in popular media. By his own account, he is bullied like any other newcomer into doing tasks that he would have otherwise refused. The city jail, Villagracia reveals, is a more brutal version of the kind of hierarchization that exists outside prison, as the more privileged inmates obtain undue favors. The VIPs-bosyo in prison parlance-commit illegalities with impunity, sometimes with the prison officials' tacit or expressed endorsement. How else to explain why some detainees could go out of prison even without a court order? How else to explain why some detainees could have exclusive use of well-ventilated and well-furnished rooms? The author wonders how and why prison officials and employees have the audacity to circumvent the 
very policies they are supposed to uphold. At one point, for example, his jail guard leaves him in one of Manila's busy streets after a court proceeding and even insinuates that it is his chance to flee. When the guard berates him for not escaping, Villagracia retorts, "Detenido ako sa Manila City Jail kaya do'n ako babalik. Kung uuwi ako sa amin, bukod sa wala akong pamasahe, tiyak na mapagbibintangan akong tumakas" (p. 50).

But the narrator's situation is more complicated than it seems. While detained, he repeatedly suffers from nervous breakdowns, which occasionally isolates him from his fellow detainees and at times almost provokes violent confrontations with them. These breakdowns were triggered by the distress brought about by the charges leveled against him. On his condition, he mused:

Nag-ugat ang karamdaman kong ito dahil sa mga dinanas kong pagsubok sa kasong criminal na may kaugnayan sa trabaho ko.... At muli, sa tuwing aatakihin ako ng sakit na ito ay nagiging dahilan din ito para maiwasan ako ng mga kakilala at ilang kamag-anak kahit noong hindi pa nakukulong sa Manila City Jail. (Villagracia, 2016, p. 73)

He even contemplated taking his own life: "Naging dahilan ang sakit na ito para naisin kong di lang wasakin ang buhay, kung hindi was akin din ito sa paniniwalang wala na akong puwang sa mundo" (Villagracia, 2016, p. 73).

But ironically, it is the other inmates who extend assistance to him in those dark and difficult days, offering him food, taking him to the prison infirmary, and providing him medicine when he needs it. To cure his boredom, he becomes friends with many of his fellow inmates with whom he exchanges stories and words of encouragement. When they find out that he has some reputation as a komiks writer, the author wins more respect from his comrades, including some of the gang leaders who wield unchecked authority like local warlords. Gang leaders even request him to write a komiks story on one of the typewriters from the jail manager's office. Like the other inmates, the narrator has to find means to survive prison life and keep his sanity intact, especially in those days when he had yet to be visited by his loved ones. He whiles away precious hours playing chess or playing the guitar. But these leisure activities could only do so much, serving only as palliatives to the overwhelming pain of loneliness and despair. Nonetheless, he remains hopeful about getting his freedom back one day. "Tingnan mo ang isda sa sardinas," he tells another inmate, "nakakalabas din sa lata kahit walang butas" (Villagracia, 2016, p. 38). 
The book employs a style that is both literary and ethnographic. There have been other first-person narratives about life in detention, some by former political prisoners who include in their stories alleged experiences of torture and other forms of harassment, as badges of honor or proofs of unswerving commitment to ideology. There are also those that sound like modern morality tales, with their protagonists experiencing enlightenment, mostly of the religious sort, and moral redemption while incarcerated. What makes Villagracia's story quite distinct is its description of the prison subculture, including of course its many unseemly aspects, from the perspective of a veritable insider.

As literature, the book has obvious deficiencies and gaps. Some of the events are not well delineated that one might think that the details are misplaced or should not have been included at all. For example, and as the narrator himself asserts, he does not know how to make sense of them-visits from strangers, cold treatment from a fellow inmate, a personality exam, getting bullied by a well-connected prisoner-and it is as if the narrator is asking readers to make their own conjectures. Some of the characters are but cursorily described. These constitute one of the book's strengths, however, for they represent in autoethnographic fashion the author's attempt to capture as much as he could what he witnessed during his relatively brief but eventful stay in prison. The book, in other words, is more concerned with communicating impressions and memories than literariness or narrative coherence. Most importantly, the narrative calls public attention to a part of society that lies in its interstices but is invariably seen as a source of moral panic. As such, Villagracia's book may be considered a "testimonio" or testimonial narrative, a protean literary form that challenges certain literary conventions. For one, while it is likened to the traditional autobiography, it foregrounds experiences of marginality and denounces forms of injustice, unlike most autobiographical accounts that revolve around individual accomplishments. The testimonio represents an attempt to democratize literature as we know it, for the author-narrator is one who does not belong to the privileged or the "published" class. Moreover, the testimonio is polyphonous or heteroglossic, the author's lived experience of subalternity intermeshed with those of others, namely Villagracia's fellow inmates. One may be reminded of Rigoberta Menchu's (1984) introductory words in her famous testimonio which foreground the collective/connective character of testimonial discourse: "It's hard for me to remember everything that's happened to me in my life since there have been many bad times but, yes, moments of joy as well. The important thing is that what has happened to me has happened to many other people, too" (p. 1). The experiences of Villagracia are not his alone; they are shared experiences 
of prisoners, particularly those who do not happen to have the connections to spare themselves from harassment or live in relative comfort even while detained.

Such narratives from groups that are generally neglected and peripheralized, even feared, deserve ample room in social history, public pedagogy, and cultural studies. If changing the world is the order of the day in these seemingly dark times, the critical engagement with Selda Dos and other works on collective experiences of injustice and marginality constitutes a crucial step. 


\section{References}

Menchu, R. (1984). I, Rigoberta Menchu: An Indian woman in Guatemala (A. Wright, Trans.). London, UK: Verso.

O'Brien, P. (2001). Making it in the free world: Women in transition from prison. Albany, NY: State University of New York Press.

Villagracia, B. (2016). Selda Dos (Manila City Jail). Quezon City, Philippines: University of the Philippines Press.

NOEL CHRISTIAN A. MORATILLA serves as Associate Professor of the Asian Center, University of the Philippines-Diliman, where he handles Philippine Studies. He earned his PhD in Philippine Studies from UP Diliman where he also obtained his MA in Language Education. His research interests include critical pedagogies, emergent cultures, and resistance literatures. (Corresponding author: nomorat@yahoo. com) 